\title{
DAMAGE TO THE LEGUME (FABACEAE) AND RAPESEED (BRASSICACEAE) PLANTS CAUSED BY ARION VULGARIS MOQUIN-TANDON, 1855, A. RUFUS (LINNAEUS, 1758) AND DEROCERAS RETICULATUM (O. F. MÜLLER, 1774)
}

\author{
JAN KOZŁOWSKI ${ }^{1 *}$, MONIKA JASKULSKA ${ }^{1}$, MARIA KOZŁOWSKA ${ }^{2}$
}

\begin{abstract}
${ }^{1}$ Department of Entomology, Animal Pests and Biotechnology, Institute of Plant Protection - National Research Institute, Władysława Węgorka 20, 60-318 Poznań, Poland (e-mail: j.kozlowski@iorpib.poznan.pl) ${ }^{2}$ Department of Mathematical and Statistical Methods, Poznań University of Life Sciences, Wojska Polskiego 28, 60-637 Poznań, Poland

*corresponding author
\end{abstract}

\begin{abstract}
In Poland, the most common pest slugs in agricultural crops are Arion vulgaris Moquin-Tandon, Deroceras reticulatum (O. F. Müller), and locally occurring Arion rufus (Linnaeus). They cause significant damage to winter oilseed rape and winter wheat. In recent years, they have also occurred in cultivations of various legume species (Fabaceae). However, information on the extent of damage caused by these species is still insufficient. To assess the extent of damage, young plants of common sainfoin, bird's-foot trefoil, red clover, alfalfa, white melilot, and oilseed rape were exposed to grazing by the slug species investigated under laboratory conditions. It was found that oilseed rape plants were more susceptible to damage by the slugs studied compared to bird's-foot trefoil plants. The susceptibility of the other plants studied varied depending on the slug species.
\end{abstract}

KEY WORDS: slugs, Fabaceae, damage

\section{INTRODUCTION}

Legume plants contribute to proper nitrogen management in the soil by nitrogen fixation and are a valuable component of nutritive fodders due to the high nutritional value of their proteins. However, they are also attractive food for numerous pests, including slugs (Gastropoda: Arionidae, Agriolimacidae). Deroceras and Arion are the most important genera of pest slugs which damage legume crops and may affect their productivity and durability (RUNHAM \& HUNTER 1970, SOUTH 1992, HANLEY 1998, BYERS 2002, BROOKS et al. 2003, KOZŁOWSKI \& JASKULSKA 2014, KOZŁOWSKI et al. 2017a, b). The plants frequently attacked by these slugs are red clover (Trifolium pratense L.), alfalfa (Medicago sativa L.), narrow-leaved lupin (Lupinus angustifolius L.), yellow lupin (L. luteus L.) and field beans (Vicia faba L.). The slugs damage seed embryos and de- stroy seedlings after the emergence of leaves, leading to significant plant damage and crop loss.

The degree of plant damage caused by slugs tends to vary. This is related to the content of nutritional components and, above all, to secondary plant metabolites which are specific to each plant species or cultivar. They have great influence on slug feeding behaviour and, consequently, the extent of plant damage (DIRZO \& HARPER 1982, AgUIAR \& WINK 1999, ESTER \& TRUL 2000, MOENS \& GLEN 2002, KOZŁOWSKI et al. 2016, 2017a). Due to the presence of metabolites each plant species has its own characteristic smell and taste which in turn makes it attractive or repellent to slugs. The fact that slugs feed on plants which they find most palatable results in their selective grazing, and influences the susceptibility of plants to damage (HANLEY 
et al. 1995, CoOK et al. 1996, FRANK \& FRIEDLI 1999). Identifying the degree of susceptibility of different plant species is an important element of developing protection strategies against slugs.

The aim of the present research was to evaluate the extent of damage caused by Arion vulgaris Moquin-Tandon, 1855, Arion rufus (Linnaeus, 1758) and Deroceras reticulatum (O. F. Müller, 1774) to five plant species of the legume family as compared with the damage to oilseed rape. The three slug species are among the most harmful ones in Europe. A. vulgaris is an invasive species, growing to a length of $12 \mathrm{~cm}$. It lives approximately one year and produces a single generation. In the last 50 years it has spread across many countries of Western, Central and Northern Europe (FRANK 1998, ANDERSON 2005, KOZŁOWSKI 2012, WeLTER-SCHULTES 2012). It occurs in various habitats, usually as a synanthropic species. As well as being a pest of vegetables and decorative plants cultivated in gardens, it also causes damage to crops, especially on field edges. A. rufus reaches $15 \mathrm{~cm}$ in length (WIKTOR 1973). It has a one-year life cycle and produces a single generation.
It is native to Western Europe and parts of Central Europe (WIKTOR 1973). It lives in the British Isles and Scandinavia (ANDERSON 2005). As an alien invasive species, it also occurs in the USA and Canada (FORSYTH 2004). The slug prefers damp habitats: lake and pond shores, river banks, forests, thickets and meadows. It causes damage to vegetables and some crops (KOZŁOWSKI 2012). D. reticulatum reaches 4.5 $\mathrm{cm}$ in length and produces one or two generations in a year. It is common in Europe, particularly in its central part (WIKTOR 2000). It has also been widely introduced to Caucasian countries, Central Asia, North and South America, South Africa, Australia, Tasmania and New Zealand (FORSYTH 2004). The species is commonly found in open habitats, much less frequently in forests and thickets. Its massive populations often occur in crops and it is regarded as one of the most dangerous pests of horticultural and agricultural crops (SOUTH 1992). Although the three slug species are increasingly found in legume cultivations, information on the extent of damage to different species of these plants is still insufficient. This study is an attempt to fill this gap in the knowledge.

\section{MATERIAL AND METHODS}

Experiments assessing the rate and extent of damage to five legume species exposed to three slug species were performed in laboratory conditions. The following species were studied: common sainfoin (Onobrychis vicifolia Scop.) - 'Taja' cultivar, bird's-foot trefoil (Lotus corniculatus L.) - 'Skrzeszowska' cultivar, red clover (Trifolium pratense L.) - 'Rozeta' cultivar, alfalfa (Medicago sativa L.) - 'Perfecta' cultivar, white melilot (Melilotus albus L.) - 'Adela' cultivar and, as a comparative plant, oilseed rape (Brassica napus var. napus L.) - 'Sy Saveo' cultivar. The plants were exposed to grazing by A. vulgaris, A. rufus and D. reticulatum. The slugs came from populations found in horticultural crops in the environs of Poznań (A. vulgaris, D. reticulatum) and Wronki (A. rufus). Young slugs collected in the spring 2017 were kept in containers

\begin{tabular}{|c|c|c|c|c|c|}
\hline 1 & 4 & 2 & 5 & 2 & 6 \\
\hline 5 & 3 & 6 & 3 & 1 & 4 \\
\hline 3 & 6 & 4 & 6 & 3 & 1 \\
\hline 1 & 5 & 2 & 4 & 2 & 5 \\
\hline 4 & 1 & 5 & 2 & 5 & 3 \\
\hline 2 & 6 & 3 & 6 & 4 & 1 \\
\hline
\end{tabular}

Fig. 1. Nested block design - diagram of arrangement of treatments (plant species) on experimental units (plots), where numbers denote: 1 - common sainfoin ('Taja'); 2 - bird's-foot trefoil ('Skrzeszowska'); 3 - white melilot ('Adela'); 4 - alfalfa ('Perfecta'); 5 - red clover ('Rozeta'); 6 - oilseed rape ('Sy Saveo'). Three plants per plot filled with $5 \mathrm{~cm}$ of soil, at $17{ }^{\circ} \mathrm{C}$ and a photoperiod of 12 hours. They were fed on pieces of vegetables (Chinese cabbage leaves, potato tubers) and wheat bran, changed twice a week. Before each experiment, the slugs were starved for 48 hours and then weighed. Individuals with the most similar weight were selected. The plants at 3-4 leaf stage were grown in raised beds in the greenhouse of the Institute of Plant Protection, National Research Institute in Poznań.

Three experiments were performed using a nested block design (Fig. 1). In each experiment, 108 plants were placed in three containers (3 superblocks) divided into two parts (2 blocks) such that there were three plants of one species on each plot. Eighteen plants of each species on six plots were planted in containers $72 \times 35 \times 15 \mathrm{~cm}$ in size in a $5 \mathrm{~cm}$-thick layer of soil. After two days, six slugs of one species were placed in the central part of each containers. The average weight of the slugs was: A. vulgaris $-1.47 \mathrm{~g}, A$. rufus $-1.53 \mathrm{~g}$, and $D$. reticulatum $-0.41 \mathrm{~g}$. The experiments were conducted in an environmental chamber with the air temperature of $17{ }^{\circ} \mathrm{C}, \mathrm{RH} 90 \% \pm 3 \%$ and the photoperiod of 12 hours. Damage to plants was assessed once a day for seven days on a 5-point scale (0; 25; 50; 75 and $100 \%$ of plant surface damaged).

Six replicates were performed for all the plant and slug species. The results were analysed with ANOVA, and the differences were assessed with the F-test at the level of significance $\alpha=0.05$ (STATISTICA software v. 12). 


\section{RESULTS}

First significant differences in the extent of plant damage occurred after the first day of grazing for all slug species. A. vulgaris caused significantly more damage to oilseed rape in comparison with other plants, except for alfalfa (Table 1). Bird's-foot trefoil and red clover were the least damaged after 24 h. After two days, oilseed rape, alfalfa and common sainfoin were more severely damaged, with no significant differences in the extent of damage. From the second day until the end of the observation, the plants of bird's-foot trefoil were significantly less damaged compared to the other plant species. After four days, oilseed rape plants sustained $100 \%$ damage, while bird's-foot trefoil plants - only $33 \%$.

After one day of grazing, A. rufus caused significantly more damage to oilseed rape and common sainfoin than to the other species (Table 2). From the second day of observation, the plants of oilseed rape and sainfoin were significantly more damaged than the plants of red clover, bird's-foot trefoil, alfalfa and white melilot. After seven days, $100 \%$ of oilseed rape plants were damaged, while the least damaged plant species was red clover (40\%). Altogether, during the entire period of slug grazing, $A$. rufus caused the most damage to oilseed rape and common sainfoin, and the least damage to red clover and bird's-foot trefoil.

After the first day of grazing, $D$. reticulatum caused significantly more damage to oilseed rape, red clover and white melilot than to bird's-foot trefoil (Table 3 ). From the second day of grazing until the end of the experiment, the slug caused severe damage also to alfalfa. Common sainfoin sustained little damage. After seven days, the most damaged plants were white melilot (94\%) and oilseed rape $(89 \%)$, whereas the least damaged ones were bird's-foot trefoil (14\%) and common sainfoin (33\%). During the seven days of grazing, $D$. reticulatum caused more damage to white melilot, rape and alfalfa than to bird'sfoot trefoil and common sainfoin.

The experiments performed showed that all the investigated slug species preferred oilseed rape plants, while bird's-foot trefoil was the least accepted species. Plant susceptibility to the damage caused by A. vulgaris was similar across all the species except for bird'sfoot trefoil, while in the case of $A$. rufus and D. reticulatum it varied for most of the plants investigated.

Table 1. Damage caused by Arion vulgaris to different plant species [\%] and results of Fisher's test; significance level $\alpha=0.05$

\begin{tabular}{llccrrrr}
\hline \multicolumn{1}{c}{ Plant species } & \multicolumn{7}{c}{ Days of grazing } \\
\cline { 2 - 8 } & \multicolumn{1}{c}{1} & 2 & 3 & 4 & 5 & 6 & 7 \\
\hline Common sainfoin (Onobrychis vicifolia) & $26.4 \mathrm{ab}$ & $69.4 \mathrm{c}$ & $81.9 \mathrm{~cd}$ & $88.9 \mathrm{bc}$ & $90.3 \mathrm{bc}$ & $100.0 \mathrm{~b}$ & 100.0 \\
Bird's-foot trefoil (Lotus corniculatus) & $11.1 \mathrm{a}$ & $19.4 \mathrm{a}$ & $25.0 \mathrm{a}$ & $33.3 \mathrm{a}$ & $40.3 \mathrm{a}$ & $54.2 \mathrm{a}$ & 73.6 \\
Red clover (Trifolium pratense) & $13.9 \mathrm{a}$ & $36.1 \mathrm{~b}$ & $59.7 \mathrm{~b}$ & $77.8 \mathrm{~b}$ & $84.7 \mathrm{~b}$ & $98.6 \mathrm{~b}$ & 100.0 \\
Alfalfa (Medicago sativa) & $43.1 \mathrm{bc}$ & $66.7 \mathrm{c}$ & $77.8 \mathrm{c}$ & $84.7 \mathrm{bc}$ & $87.5 \mathrm{bc}$ & $95.8 \mathrm{~b}$ & 100.0 \\
White melilot (Meliotus albus) & $33.3 \mathrm{~b}$ & $43.1 \mathrm{~b}$ & $68.1 \mathrm{bc}$ & $83.3 \mathrm{~b}$ & $87.5 \mathrm{bc}$ & $95.8 \mathrm{~b}$ & 100.0 \\
Oilseed rape (Brassica napus) & $59.7 \mathrm{c}$ & $80.6 \mathrm{c}$ & $98.6 \mathrm{~d}$ & $100.0 \mathrm{c}$ & $100.0 \mathrm{c}$ & $100.0 \mathrm{~b}$ & 100.0 \\
\hline
\end{tabular}

Values in columns marked with at least one same letter do not differ significantly.

Table 2. Damage caused by Arion rufus to different plant species [\%] and results of Fisher's test; significance level $\alpha=0.05$

\begin{tabular}{lccccccc}
\hline \multicolumn{1}{c}{ Plant species } & \multicolumn{7}{c}{ Days of slug feeding } \\
\cline { 2 - 7 } & 1 & 2 & 3 & 4 & 5 & 6 & 7 \\
\hline Common sainfoin (Onobrychis vicifolia) & $44.4 \mathrm{c}$ & $83.3 \mathrm{c}$ & $87.5 \mathrm{c}$ & $91.7 \mathrm{c}$ & $91.7 \mathrm{c}$ & $91.7 \mathrm{c}$ & $94.4 \mathrm{~cd}$ \\
Bird's-foot trefoil (Lotus corniculatus) & $13.9 \mathrm{ab}$ & $23.6 \mathrm{ab}$ & $27.8 \mathrm{a}$ & $34.7 \mathrm{a}$ & $36.1 \mathrm{a}$ & $44.4 \mathrm{a}$ & $50.0 \mathrm{a}$ \\
Red clover (Trifolium pratense) & $6.9 \mathrm{a}$ & $13.9 \mathrm{a}$ & $20.8 \mathrm{a}$ & $30.6 \mathrm{a}$ & $31.9 \mathrm{a}$ & $34.7 \mathrm{a}$ & $40.3 \mathrm{a}$ \\
Alfalfa (Medicago sativa) & $26.4 \mathrm{~b}$ & $34.7 \mathrm{~b}$ & $43.1 \mathrm{~b}$ & $56.9 \mathrm{~b}$ & $65.3 \mathrm{~b}$ & $69.4 \mathrm{~b}$ & $73.6 \mathrm{~b}$ \\
White melilot (Meliotus albus) & $18.1 \mathrm{ab}$ & $30.6 \mathrm{~b}$ & $43.1 \mathrm{~b}$ & $52.8 \mathrm{~b}$ & $65.3 \mathrm{~b}$ & $68.1 \mathrm{~b}$ & $77.8 \mathrm{bc}$ \\
Oilseed rape (Brassica napus) & $58.3 \mathrm{c}$ & $80.6 \mathrm{c}$ & $91.7 \mathrm{c}$ & $95.8 \mathrm{c}$ & $97.2 \mathrm{c}$ & $97.2 \mathrm{c}$ & $100.0 \mathrm{~d}$ \\
\hline
\end{tabular}

Values in columns marked with at least one same letter do not differ significantly.

Table 3. Damage caused by Deroceras reticulatum to different plant species [\%] and results of Fisher's test; significance level $\alpha=0.05$

\begin{tabular}{|c|c|c|c|c|c|c|c|}
\hline \multirow{2}{*}{ Plant species } & \multicolumn{7}{|c|}{ Days of slug feeding } \\
\hline & 1 & 2 & 3 & 4 & 5 & 6 & 7 \\
\hline Common sainfoin (Onobrychis vicifolia) & $9.7 \mathrm{ab}$ & $12.5 \mathrm{a}$ & $15.3 \mathrm{a}$ & $16.7 \mathrm{a}$ & $25.0 \mathrm{a}$ & $29.2 \mathrm{~b}$ & $33.3 \mathrm{~b}$ \\
\hline Bird's-foot trefoil (Lotus corniculatus) & $2.8 \mathrm{a}$ & $2.8 \mathrm{a}$ & $5.6 \mathrm{a}$ & $6.9 \mathrm{a}$ & $9.7 \mathrm{a}$ & $11.1 \mathrm{a}$ & $13.9 \mathrm{a}$ \\
\hline Red clover (Trifolium pratense) & $20.8 \mathrm{~b}$ & $34.7 \mathrm{~b}$ & $45.8 \mathrm{~b}$ & $48.6 \mathrm{~b}$ & $56.9 \mathrm{~b}$ & $62.5 \mathrm{c}$ & $73.6 \mathrm{c}$ \\
\hline Alfalfa (Medicago sativa) & $11.1 \mathrm{ab}$ & $31.9 \mathrm{~b}$ & $48.6 \mathrm{~b}$ & $65.3 \mathrm{c}$ & $70.8 \mathrm{~b}$ & $75.0 \mathrm{~cd}$ & $86.1 \mathrm{~cd}$ \\
\hline White melilot (Meliotus albus) & $20.8 \mathrm{~b}$ & $33.3 \mathrm{~b}$ & $50.0 \mathrm{~b}$ & $63.9 \mathrm{c}$ & $70.8 \mathrm{~b}$ & $84.7 \mathrm{~d}$ & $94.4 \mathrm{~d}$ \\
\hline Oilseed rape (Brassica napus) & $18.1 \mathrm{~b}$ & $36.1 \mathrm{~b}$ & $41.7 \mathrm{~b}$ & $51.4 \mathrm{bc}$ & $62.5 \mathrm{~b}$ & $72.2 \mathrm{~cd}$ & $88.9 \mathrm{~d}$ \\
\hline
\end{tabular}

Values in columns marked with at least one same letter do not differ significantly. 


\section{DISCUSSION}

The primary aim of the study was to assess the susceptibility of the selected legumes and oilseed rape to grazing and damage caused by $A$. vulgaris, $A$. rufus and $D$. reticulatum. The tests were performed on plants in their early stage of growth (3-4 true leaf stage), i.e. when they are most vulnerable to slug grazing (BYERS 2002, BARLOW et al. 2013). The method used in the experiments was choice tests which allow for assessing which plants are the most attractive food for slugs. Our results showed that oilseed rape was preferred by all the investigated slug species. A. vulgaris and A. rufus, caused, respectively, $100 \%$ and $96 \%$ damage to the plants after four days of grazing. In the case of $D$. reticulatum, whose weight was three times lower compared to the other species, the rate of damage was lower. However, after seven days of grazing, the damage caused by this species was almost $90 \%$. The high palatability of oilseed rape has been known since the emergence of cultivars with lower glucosinolate content (6-12 $\mathrm{mg} \mathrm{g}^{-1}$ in seeds). Glucosinolates are known to have a deterrent effect on slugs (PORT \& PORT 1986, SOUTH 1992, BYRNE \& JONES 1996, FRANK 1998, MOENS \& GLEN 2002). In the past, rape cultivars used to contain high amounts of these substances (70-90 mg $\mathrm{g}^{-1}$ in seeds), which made them very unattractive to slugs. As a result, the extent of damage was negligible from the economic point of view (MOENS \& GLEN 2002). The present study showed that, apart from oilseed rape, $A$. rufus and $D$. reticulatum also caused severe damage to alfalfa, while A. rufus - to common sainfoin, which was little damaged by $D$. reticulatum. $D$. reticulatum also preferred white melilot, while $A$. rufus showed little preference towards red clover and bird's-foot trefoil. High preference for white melilot shown by $D$. reticulatum and little acceptance of red clover observed in A. rufus was also found in a previous study (KoZŁOWSKI et al. 2017b) in which the plants were compared with white mustard, serradella and vetch. The results of the present study indicate that food preferences of $A$. rufus and D. reticulatum are more varied with respect to the plant species investigated than those demonstrated by $A$. vulgaris. A similar conclusion was formulated in an earlier study (KOZŁOWSKI et al. 2017b).

An interesting observation is the small susceptibility of bird's-foot trefoil (L. corniculatus) to dam- age caused by $A$. vulgaris, A. rufus and D. reticulatum. Similar results were obtained with regard to other slug species. Based on their laboratory studies, BYERS \& BIERELEIN (1982) concluded that D. reticulatum, D. laeve and A. fasciatus preferred seedlings of red clover and alfalfa to those of bird's-foot trefoil. These findings generally corroborated the data from field experiments which demonstrated a low susceptibility of bird's-foot trefoil in comparison with alfalfa (BYERS 2002). It is known that some forms of bird's-foot trefoil (L. corniculatus) and white clover (Trifolium repens) may contain cyanogenic glycosides which have a deterrent effect on many herbivores, including slugs (JONES 1966, DIRZO \& HARPER 1982). Once damaged by a herbivore, these compounds release hydrogen cyanide ( $\mathrm{HCN})$. It is toxic to animals, primarily due to the fact that it inhibits the activity of cytochrome oxidase in the mitochondrial respiratory chain. Using choice tests, JONES (1966) showed that $D$. reticulatum first fed on non-cyanogenic forms of $L$. corniculatus and began to eat the cyanogenic ones only when the others were not available. This shows that slugs tend to avoid plants containing these substances. Plants of bird's-foot trefoil used in our research may have contained cyanogenic glycosides which inhibited slug grazing. This possibility will be explored in further studies on the extent of damage to cyanogenic and non-cyanogenic forms of bird's-foot trefoil and white clover caused by slugs.

The results of the present study show that the susceptibility of legume plants to damage caused by slugs varies. Determination of the extent of plants' susceptibility to damage caused by slugs has an important application in practice. After verification in field conditions, these data will be used to predict the extent of damage to legumes, and implemented in programmes of integrated protection of these plants in areas inhabited by A. vulgaris, A. rufus and D. reticulatum.

\section{ACKNOWLEDGEMENTS}

The study was supported by the Polish Ministry of Agriculture and Rural Development within the statutory regulations of The Institute of Plant Protection - National Research Institute: AGROBIO-02.

ANDERSON R. 2005. An annotated list of the non-marine Mollusca of Britain and Ireland. Journal of Conchology 38: 607-637.

BARlow S. E., Close A. J., PORT G. R. 2013. The acceptability of meadow plants to the slug Deroceras reticulatum ciation, 20-24 June 1999, Canterbury, New Zeeland: 97-98. 
and implications for grassland restoration. Annals of Botany 112: 721-730. https://doi.org/10.1093/aob/ mct086

Brooks A. S., Crook M. J., Wilcox A., CoOK R. T. 2003. A laboratory evaluation of the palatability of legumes to the field slug Deroceras reticulatum Müller. Pest Management Science 59: 245-251. https://doi. org/10.1002/ps.658

BYERS R. A. 2002. Agriolimacidae and Arionidae as pests in lucerne and other legumes in forage systems of north-eastern North America. In: BARKER G. M. (ed.). Molluscs as crop pests. CABI, Hamilton, New Zealand, pp. 325-335. https://doi.org/ $10.1079 / 9780851993201.0325$

BYERS R. A., BIERLEIN D. L. 1982. Feeding preferences of three slug species in the laboratory. Melscheimer Entomological Series 32: 5-11.

BYRNE J., JONES P. 1996. Responses to glucosinolate content in oilseed rape varieties by crop pest (Deroceras reticulatum) and non-pest slug species (Limax pseudoflavus). Annals of Applied Biology 128 (suppl.): 78-79. https://doi.org/10.1111/j.1744-7348.1996.tb07918.x

COOK R. T., BAILEY S. E. R., MCCROHAN C. R. 1996. Slug preference for winter wheat cultivars and common agricultural weeds. Journal of Applied Ecology 33: 866872. https://doi.org/10.2307/2404957

DiRzO R., HARPER J. L. 1982. Experimental studies on slug-plant interactions. IV. The performance of cyanogenic and acyanogenic morphs of Trifolium repens in the field. Journal of Ecology 70: 119-138. https://doi. org/10.2307/2259868

ESTER A., TRUL R. 2000. Slug damage and control of field slug (Deroceras reticulatum (Müller)) by carvone in stored potatoes. Potato Research 43: 253-261. https:// doi.org/10.1007/BF02358084

FORSYTH R. G. 2004. Land snails of British Columbia. Royal British Columbia Museum, Canada.

FRANK T. 1998. Slug damage and numbers of the slug pests Arion lusitanicus and Deroceras reticulatum in oilseed rape grown beside sown wildflower strips. Agriculture, Ecosystems \& Environment 67: 67-78. https://doi org/10.1016/S0167-8809(97)00108-4

FRANK T., FRIEDLI J. 1999. Laboratory food choice trials to explore the potential of common weeds to reduce slug feeding on oilseed rape. Biological Agriculture and Horticulture 17: 19-29. https://doi.org/10.1080/0144 8765.1999.9754821

HANLEY M. E. 1998. Seedling herbivory, community composition and plant life history traits. Perspectives in Plant Ecology, Evolution and Systematics 1: 191-205. https://doi.org/10.1078/1433-8319-00058

HANLEY M. E., FENNER M., EDWARDS P. J. 1995. The effect of seedling age on the likelihood of herbivory by the slug Deroceras reticulatum. Functional Ecology 9: 754759. https://doi.org/10.2307/2390248
JONES D. A. 1966. On the polymorphism of cyanogenesis in Lotus corniculatus L. I. Selection by animals. Canadian Journal Genetics and Cytology 8: 556-567. https://doi. org/10.1139/g66-067

KoZŁOWSKI J. 2012. The significance of alien and invasive slug species for plant communities in agrocenoses. Journal of Plant Protection Research 52: 67-76. https:// doi.org/10.2478/v10045-012-0012-9

KOZŁOWSKI J., JASKULSKA M. 2014. The effect of grazing by the slugs Arion vulgaris, Arion rufus and Deroceras reticulatum (Gastropoda: Pulmonata: Stylommatophora) on extent of damage to leguminous plants and other small-area crops. Journal of Plant Protection Research 54: 258-266. https://doi.org/10.2478/jppr-2014-0039

KOZŁOWSKI J., JASKULSKA M., KOZŁOWSKA M. 2017a. The role of alkaloids in the feeding behaviour of slugs (Gastropoda: Stylommatophora) as pests of narrowleafed lupin plants. Acta Agriculturae Scandinavica, Section B, Soil \& Plant Science 67: 263-269.

KozŁOWSKI J., JASKUlSKA M., KOZŁOWSKA M. 2017b. Evaluation of damage caused by slugs (Gastropoda: Arionidae, Agriolimacidae) to selected agricultural plants. Progress in Plant Protection 57: 141-145.

KOZŁOWSKI J., STRAŻYŃSKI P., JASKULSKA M., KOZŁOWSKA M. 2016. Relationships between aphids (Insecta: Homoptera: Aphididae) and slugs (Gastropoda: Stylommatophora: Agriolimacidae) pests of legumes (Fabaceae: Lupinus). Journal of Insect Science 16: 52 (1-7). https://doi.org/10.1093/jisesa/iew033

Moens R., Glen D. M. 2002. Agriolimacidae, Arionidae and Milacidae as pests in west European oilseed rape. In: BARKER G. M. (ed.). Molluscs as crop pests. CABI, Hamilton, New Zealand, pp. 301-314. https://doi. org/10.1079/9780851993201.0425

PORT C. M., PORT G. R. 1986. The biology and behavior of slugs in relation to crop damage and control. Agricultural Zoology Reviews 1: 255-299.

RUNHAM N. W., HunTER P. J. 1970. Terrestrial slugs. Hutchinson and Co. Ltd., London, UK.

SouTH A. 1992. Terrestrial slugs: biology, ecology, and control. Chapman and Hall, London. https://doi. org/10.1007/978-94-011-2380-8

WELTER-SCHULTES F. W. 2012. European non-marine molluscs, a guide for species identification. Plant Poster Editions, Göttingen.

WIKTOR A. 1973. Die Nacktschnecken Polens - Arionidae, Milacidae, Limacidae (Gastropoda, Stylommatophora). Monografie Fauny Polski 1, Warszawa-Kraków.

WIKTOR A. 2000. Agriolimacidae (Gastropoda: Pulmonata) a systematic monograph. Annales Zoologici 49: 155157.

Received: July 24th, 2018

Revised: October 29th, 2018

Accepted: November 5th, 2018

Published on-line: December 11th, 2018 